\title{
Lactobacillus suntoryeus sp. nov., isolated from malt whisky distilleries
}

Correspondence

Fergus G. Priest

f.g.priest@hw.ac.uk

\author{
Elise Cachat and Fergus G. Priest
}

International Centre for Brewing and Distilling, School of Life Sciences, Heriot-Watt University, Edinburgh EH14 4AS, UK

\begin{abstract}
Eight strains of Lactobacillus with identical partial 16S rRNA gene sequences and similar randomly amplified polymorphic DNA patterns were isolated from fermentation samples from Japanese and Scottish malt whisky distilleries. Phylogenetic analysis of almost complete 16S rRNA gene sequences from three representative strains (two from Japan, one from Scotland) placed them in the genus Lactobacillus as members of the Lactobacillus acidophilus group. Lactobacillus helveticus and Lactobacillus gallinarum were the most closely related species, with 16S rRNA gene similarities of 99.3 and $98.1 \%$, respectively. A similar phylogeny was derived from partial sequences of elongation factor Tu (tuf) genes in which the alleles from the three distillery isolates were identical and shared $99.0 \%$ similarity with $L$. helveticus and $L$. gallinarum tuf genes. S-layer $(s / p)$ gene sequences suggested different relationships among the strains and the distillery isolates no longer formed a monophyletic group. The alleles from the Japanese and Scottish strains shared only $54 \%$ similarity. Chromosomal DNA from the distillery strains gave DNA-DNA hybridization values between 79 and $100 \%$ but showed less than 43 and $22 \%$ reassociation with $L$. helveticus and $L$. gallinarum DNA, respectively. The name Lactobacillus suntoryeus sp. nov. is proposed for this novel taxon; the type strain is strain $\mathrm{SA}^{\top}$ (=LMG $22464^{\top}=\mathrm{NCIMB} 14005^{\mathrm{T}}$ ).
\end{abstract}

Lactic acid bacteria comprise a natural component of the microflora of malt whisky fermentation (Simpson et al., 2001; van Beek \& Priest, 2002). In well-maintained distilleries their numbers are low at the beginning of the fermentation, but, once the yeast has completed the alcoholic fermentation, they grow prolifically during the 'late lactic fermentation' and are considered to confer positive flavour notes to the spirit (Takatani \& Ikemoto, 2004). The most common species encountered are Lactobacillus brevis, Lactobacillus fermentum and Lactobacillus paracasei, but numerous other Lactobacillus species, lactococci, leuconostocs and weissellas have been detected, particularly in the early stages of the fermentation, when the alcohol concentration is relatively low (van Beek \& Priest, 2003).

Analysis of Scotch whisky fermentations using denaturing gradient gel electrophoresis revealed an uncultured bacterium in the late stages of fermentation that was closely related to a bacterium isolated from a Japanese malt whisky fermentation and referred to as strain Y10. Phylogenetic

Published online ahead of print on 19 July 2004 as DOI 10.1099/ ijs.0.63266-0.

The GenBank/EMBL/DDBJ accession number for the 16S rRNA gene sequence of strain $S A^{\top}$ is $A Y 445815$.

RAPD profiles and a neighbour-joining tree based on partial tuf gene sequences are available as supplementary material in IJSEM Online. studies based on the 16S rRNA gene sequence of strain Y10 suggested that this bacterium was a member of the Lactobacillus acidophilus group (van Beek \& Priest, 2002). This group comprises L. acidophilus sensu stricto, Lactobacillus amylovorus, Lactobacillus crispatus, Lactobacillus gallinarum, Lactobacillus gasseri, Lactobacillus helveticus and Lactobacillus johnsonii (Johnson et al., 1980; Fujisawa et al., 1992; Gancheva et al., 1999), with three relatively recent additions: Lactobacillus amylolyticus, isolated from malt and beer wort (Bohak et al., 1998), Lactobacillus iners, associated with human sources (Falsen et al., 1999) and Lactobacillus kitasatonis, from chicken intestines (Mukai et al., 2003). In this study, we have investigated the phylogenetic relationships between the Japanese and Scottish isolates from whisky fermentations and shown that they constitute a distinct taxon within the L. acidophilus lineage, for which we propose the name Lactobacillus suntoryeus sp. nov.

Eight strains of lactic acid bacteria were isolated from four different distilleries in Japan and Scotland. The Japanese strains were isolated on three occasions: strains Y10, H8 and W6 in 1989, strains YD, HD and PD in 1993 and strain $\mathrm{SA}^{\mathrm{T}}$ in 1999. Strains Y10, YD and $\mathrm{SA}^{\mathrm{T}}$ were isolated from the Yamazaki distillery, strains H8, W6 and HD from the Hakushu distillery and PD from the Suntory pilot plant. Strain M4 was isolated from the Glenkinchie distillery in southern Scotland in 2002. For isolation of strain M4, a 
fermentation sample was diluted in MRS broth, plated onto MRS agar (Oxoid) supplemented with maltose $\left(10 \mathrm{~g} \mathrm{l}^{-1}\right)$, brain heart infusion broth (Oxoid; $10 \mathrm{~g} \mathrm{l}^{-1}$ ) and cycloheximide $\left(100 \mu \mathrm{g} \mathrm{ml}^{-1}\right)$ and incubated anaerobically for $48 \mathrm{~h}$ at $37^{\circ} \mathrm{C}$. Isolated colonies were purified on the same medium by streak plating three times and a representative isolate was stored at $-70^{\circ} \mathrm{C}$ in MRS broth containing $20 \%$ (v/v) glycerol as strain M4. Distillery isolates were routinely cultured on supplemented MRS agar or broth (without cycloheximide) at $37^{\circ} \mathrm{C}$ anaerobically. The main reason why these organisms had not been recovered in earlier studies (e.g. Makanjuola \& Springham, 1984; Simpson et al., 2001) was probably due to their growth requirements; they grow poorly, if at all, unless MRS-based media are supplemented with brain heart infusion or similar. Reference strains L. gallinarum DSM $10532^{\mathrm{T}}$ and L. helveticus NCIMB $11971^{\mathrm{T}}$ were obtained from the Deutsche Sammlung von Mikroorganismen und Zellkulturen (DSMZ) and the National Collection of Industrial and Marine Bacteria (NCIMB), respectively, and cultured in MRS agar or broth at $37^{\circ} \mathrm{C}$.

Chromosomal DNA was isolated using the PUREGENE DNA Isolation kit (Gentra Systems) from cultures grown in supplemented MRS broth for $24 \mathrm{~h}$ at $37^{\circ} \mathrm{C}$. The manufacturer's protocol for DNA isolation from Gram-positive bacteria was modified by the addition of $140 \mathrm{U}$ mutanolysin (Sigma) $\mathrm{ml}^{-1}$ and $50 \mu \mathrm{g}$ lysozyme (Sigma) $\mathrm{ml}^{-1}$ to the lytic enzyme solution and the suspension was incubated at $37^{\circ} \mathrm{C}$ for $45 \mathrm{~min}$ to effect lysis. Larger amounts of DNA were prepared by phenol extraction as described previously (Simpson et al., 2001). DNA concentration was determined by the diphenylamine method (Burton, 1968). Randomly amplified polymorphic DNA (RAPD) patterns were generated as described previously (Simpson et al., 2001).

Fragments of genes for sequence determination were amplified by PCR using the following reaction mixture $(50 \mu \mathrm{l})$ : $5 \mu \mathrm{l}$ DyNAzyme EXT buffer (Finnzymes), $1 \mu \mathrm{l} 10 \mathrm{mM}$ dNTPs, $2 \mu \mathrm{l} 50 \mathrm{mM} \mathrm{MgCl}$, 10 pmol each primer, $100 \mathrm{ng}$ DNA and $1 \mathrm{U}$ DyNAzyme EXT polymerase. Amplifications were performed with the following thermal cycle: $95^{\circ} \mathrm{C}$ for $5 \mathrm{~min}, 30$ cycles of $95^{\circ} \mathrm{C}$ for $10 \mathrm{~s}$, an annealing step of $1 \mathrm{~min}$ (temperature specified below) and elongation at $72{ }^{\circ} \mathrm{C}$ for $2 \mathrm{~min}$, with a final elongation step at $72^{\circ} \mathrm{C}$ for 10 min. 16S rRNA genes were amplified using universal primers $27 \mathrm{f}\left(5^{\prime}\right.$-AGAGTTTGATCMTGGCTCAG- $\left.3^{\prime}\right)$ and 1492r (5'-TACGGYTACCTTGTTACGACTT-3'), with an annealing temperature of $56^{\circ} \mathrm{C}$. $t u f$ genes were amplified using primers tuf-01-f ( $5^{\prime}$-GTTGTTGCTGCAACTGATGG-3') and tuf-02-r (5'-CCATTTCAGTACCTTCTGGC$\left.3^{\prime}\right)$, with an annealing temperature of $56^{\circ} \mathrm{C}$. These were designed from an alignment of $t u f$ gene sequences from L. acidophilus, L. amylovorus, L. crispatus, L. gallinarum and $L$. helveticus and enabled amplification of a region from nt 19 to 760 (numbering according to the L. acidophilus ATCC $4356^{\mathrm{T}}$ gene sequence). S-layer genes were amplified using various primers with corresponding annealing temperatures. The initial primers S01-f ( $5^{\prime}$-AGAATYGTTAGCGYTGCTGC-3') and S02-r (5'-CGTTGTGCTTCAAAGTACGC- $\left.3^{\prime}\right)$ at $50^{\circ} \mathrm{C}$ enabled partial sequencing of the $5^{\prime}$ end of the PCR products from all four strains (three distillery isolates and L. gallinarum DSM $10532^{\mathrm{T}}$ ). New primers were then prepared for strains $\mathrm{SA}^{\mathrm{T}}$ and $\mathrm{Y} 10, \mathrm{~S} 03-\mathrm{f}$ (5'-GACCACATGAAGAAAAATTT- $\left.3^{\prime}\right)$ and Jap3-S04-r (5'-CAGCACCATCAACAGCAATA- $\left.3^{\prime}\right)$ at $50^{\circ} \mathrm{C}$; for strain M4, S01-f and M4-S04-r (5'-TCGTCAGCAGTAGTAGATGG-3') at $50^{\circ} \mathrm{C}$; and for L. gallinarum DSM $10532^{\mathrm{T}}$, S01-f and galli-S04-r (5'-GTTCATAGCCTTAAGAGCTG$\left.3^{\prime}\right)$ at $56^{\circ} \mathrm{C}$, as conserved regions suitable for all strains were not available. This resulted in fragments of $848 \mathrm{bp}$ (nt 49-896) for strains Y10 and SA ${ }^{\mathrm{T}}, 711$ bp (nt 70-780) for strain M4 and 808 bp (nt 70-877) for L. gallinarum DSM $10532^{\mathrm{T}}$ all based on L. acidophilus ATCC $4356^{\mathrm{T}}$ gene sequence numbering. PCR products were purified by $\mathrm{PEG}_{8000}$ precipitation and sequenced using the ABI Prism Big Dye Terminator cycle sequencing ready reaction kit and the ABI 310 capillary sequencing system (Applied Biosystems). Due to the presence of multiple copies of the S-layer gene in L. gallinarum DSM $10532^{\mathrm{T}}$, PCR products were cloned in Escherichia coli with the TOPO TA Cloning kit (Invitrogen) and sequenced after PCR amplification with primers S01-f and galli-S04-r as described above. Alignments were prepared with CLUSTAL X and phylogenetic trees were constructed using PAUP 4 (http://paup.csit.fsu.edu/).

For DNA-DNA hybridizations, probe DNAs were labelled with digoxigenin using random-priming and the DIG High Prime DNA Labelling and Detection Starter kit II (Roche). DNA $(1 \mu \mathrm{g})$ was immobilized on nylon membranes, hybridized at $42{ }^{\circ} \mathrm{C}$ and washed at high stringency $\left(65^{\circ} \mathrm{C}\right)$ as described previously (Simpson et al., 2001). Labelled probe was detected by chemiluminescence and quantified with ImageMaster TotalLab software (Amersham Pharmacia Biotech).

Partial 16S rRNA gene sequences (around $300 \mathrm{bp}$ from the $5^{\prime}$ end) of the eight strains were identical. RAPD analysis provided further evidence that the distillery isolates were closely related. RAPD patterns are highly discriminatory for members of the L. acidophilus group and can be used to distinguish strains of the various species, as well as to provide discrimination within species (Du Plessis \& Dicks, 1995; Gancheva et al., 1999; Ventura \& Zink, 2002). The identical patterns generated from strains $\mathrm{SA}^{\mathrm{T}}$ and $\mathrm{Y} 10$ and the very similar pattern from strain M4 were consistent with the isolates belonging to a single species (see Supplementary Fig. A available in IJSEM Online).

The virtually complete $16 \mathrm{~S}$ rRNA gene sequences of strains $\mathrm{SA}^{\mathrm{T}}$, Y10 and M4 and of L. helveticus NCIMB $11971^{\mathrm{T}}$ were determined and a phylogenetic tree was constructed using $16 S$ rRNA gene sequences retrieved from GenBank for other members of the L. acidophilus group and L. brevis. The three distillery isolates had identical 16S rRNA gene sequences and the tree topology confirmed that they were members of the $L$. acidophilus group (Fig. 1). The 16S rRNA 


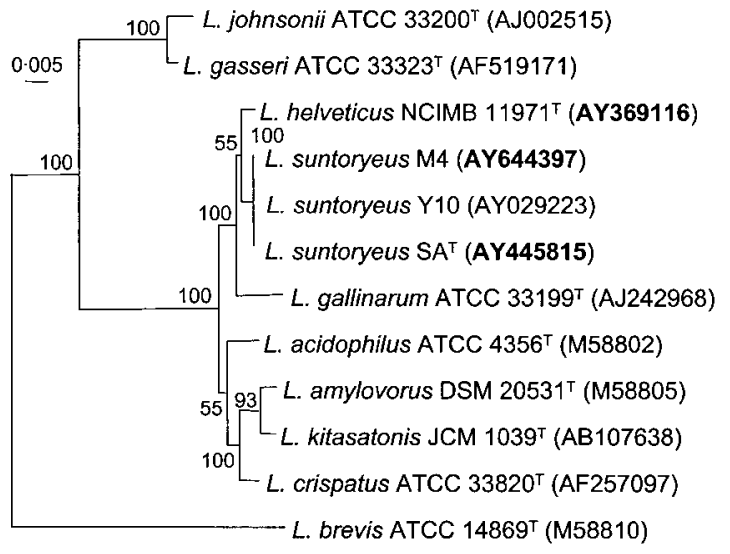

Fig. 1. Neighbour-joining tree showing the relationships of the distillery isolates with reference strains of the $L$. acidophilus group based on 16S rRNA gene sequences. L. brevis was used as an outgroup. Bootstrap values (expressed as percentages of 1000 replications) are shown at branch points. Sequences generated in this study are indicated in bold. Bar, 0.005 substitutions per site.

genes of these strains shared $99 \cdot 3$ and $98 \cdot 1 \%$ sequence similarity with $L$. helveticus and L. gallinarum 16S rRNA genes, respectively.

To differentiate further between the distillery isolates and their relatives, we analysed two protein-coding genes, the tuf gene, which encodes the translational elongation factor Tu (Chavagnat et al., 2002) and slp, which encodes a surfacelayer protein. A neighbour-joining tree based on partial sequences of $681 \mathrm{bp}$ of the tuf genes fully supported the tree topology obtained with $16 \mathrm{~S}$ rRNA gene sequences. The three distillery isolates had identical tuf alleles and were again most closely related to L. helveticus and L. gallinarum (see Supplementary Fig. B available in IJSEM Online), confirming the value of this gene as a reliable indicator of phylogenetic relationships within this group of bacteria (Chavagnat et al., 2002).

Lactobacilli of the L. acidophilus group, apart from $L$. johnsonii and L. gasseri, possess a highly variable surfacelayer protein (Boot et al., 1996) that has been used as a taxonomic tool for identification of L. crispatus (Horie et al., 2002). We amplified and sequenced partial slp genes from the three distillery isolates and L. gallinarum DSM $10532^{\mathrm{T}}$. The topology of the neighbour-joining tree constructed from these sequences and homologous sequences from GenBank (Fig. 2) differed from that based on 16S rRNA and $t u f$ genes, and the distillery isolates did not form a monophyletic group. Indeed, the allele of strain M4 shared very low sequence similarity (approx. 54\%) with those of the Japanese strains. Surface-protein genes are subject to greater selective pressure and change more rapidly than housekeeping genes such as tuf, particularly in pathogenic bacteria exposed to immune responses

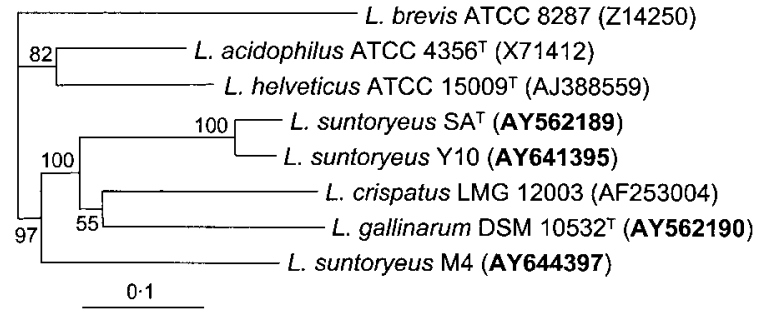

Fig. 2. Neighbour-joining tree showing the relationships of the distillery isolates with reference strains of the $L$. acidophilus group based on s/p gene sequences. L. brevis was used as an outgroup. Bootstrap values (expressed as percentages of 1000 replications) are shown at branch points. Sequences generated in this study are indicated in bold. Bar, 0.1 substitutions per site.

(van Loo et al., 2002). The inconsistencies between the slp tree and those derived from 16S rRNA and tuf genes indicated that the $s l p$ gene may not provide an accurate picture of the phylogenetic relationships of these organisms and may be subject to lateral transfer.

Since the 16S rRNA and tufgene sequences showed that the distillery isolates were most closely related to L. gallinarum and $L$. helveticus, we established the status of these strains by DNA hybridization. Probe DNA from strains $\mathrm{SA}^{\mathrm{T}}$ and M4 gave DNA-DNA hybridization values between 79 and $100 \%$ with each other and with DNA from strain Y10. Hybridization between the two probe DNAs and DNA from L. gallinarum DSM $10532^{\mathrm{T}}$ and L. helveticus NCIMB $11971^{\mathrm{T}}$ was less than $43 \%$, establishing the distillery isolates as representatives of a novel species.

The three distillery strains $\mathrm{SA}^{\mathrm{T}}$, Y10 and M4 were all Grampositive, catalase-negative homofermentative rods. After anaerobic incubation in modified MRS broth for $24 \mathrm{~h}, \mathrm{SA}^{\mathrm{T}}$ cells were rods approximately $10 \mu \mathrm{m}$ long (ranging from 2 to $30 \mu \mathrm{m}$ ), M4 cells were smaller (from 2 to $15 \mu \mathrm{m}$ ) and Y10 cells formed long filaments (from 20 to $200 \mu \mathrm{m}$ ). The carbohydrate fermentation patterns of the three distillery strains and L. gallinarum DSM $10532^{\mathrm{T}}$ were determined using the API $50 \mathrm{CHL}$ system (bioMérieux). The three distillery strains had similar profiles except for the production of acid from galactose and starch, which was positive for strain M4 and negative for strains $\mathrm{SA}^{\mathrm{T}}$ and Y10 (Table 1). The phylogenetic analyses, DNA hybridization results and distinguishing phenotypic characteristics (Table 1) confirmed these bacteria as members of a novel species, for which we propose the name Lactobacillus suntoryeus sp. nov. in recognition of the first isolation of these bacteria.

\section{Description of Lactobacillus suntoryeus sp. nov.}

Lactobacillus suntoryeus (sun.to.ry.e'us. N.L. masc. adj. suntoryeus occurring in Suntory malt whisky fermentations). 
Table 1. Differential carbohydrate fermentation reactions of distillery isolates compared with related strains of the $L$. acidophilus group

Taxa: 1, L. suntoryeus sp. nov. strains $\mathrm{SA}^{\mathrm{T}}$ and $\mathrm{Y} 10 ; 2$, L. suntoryeus sp. nov. M4; 3, L. acidophilus; 4, L. crispatus; 5, L. gallinarum DSM $10532^{\mathrm{T}} ; 6$, L. helveticus. Data in columns 3, 4 and 6 adapted from API 50 CHL literature; other results determined in this study. Characters are scored as:,$+ 85-100 \%$ positive; $(+)$, $75-84 \%$ positive; $\mathrm{V}$, variable $(26-74 \%$ positive); (-), $16-25 \%$ positive; -, $0-15 \%$ positive. Results for the other fermentation reactions are given in the species description.

\begin{tabular}{|lcccccc|}
\hline Acid from: & $\mathbf{1}$ & $\mathbf{2}$ & $\mathbf{3}$ & $\mathbf{4}$ & $\mathbf{5}$ & $\mathbf{6}$ \\
\hline Cellobiose & + & + & + & + & + & - \\
Galactose & - & + & $(+)$ & $(+)$ & + & + \\
Gentiobiose & + & + & + & $\mathrm{V}$ & + & - \\
Glycogen & - & - & - & $\mathrm{V}$ & + & - \\
Raffinose & - & - & $(-)$ & $\mathrm{V}$ & + & - \\
Starch & - & + & $(-)$ & + & + & - \\
Trehalose & - & - & $(+)$ & $\mathrm{V}$ & - & $\mathrm{V}$ \\
\hline
\end{tabular}

Gram-positive rods varying in length from $2 \mu \mathrm{m}$ to long filaments. Non-motile, non-sporulating and catalase negative. After $48 \mathrm{~h}$ incubation on MRS agar (supplemented with maltose and brain heart infusion broth), colonies are circular, shiny, creamy white in colour and 2-5 mm in diameter. Growth is poor in unsupplemented MRS medium. Growth occurs at 37 and $45^{\circ} \mathrm{C}$, but not at $15^{\circ} \mathrm{C}$. Strictly homofermentative. Acid is produced from $\mathrm{N}$-acetyl glucosamine, amygdalin, arbutin, cellobiose, aesculin, fructose, gentiobiose, glucose, maltose, mannose, salicin, sucrose and in some cases from galactose and starch (type strain negative). Adonitol, D-arabinose, L-arabinose, Dand L-arabitol, dulcitol, erythritol, D- and L-fucose, gluconate, glycerol, inositol, inulin, 2-ketogluconate, 5ketogluconate, D-lyxose, mannitol, melezitose, methyl $\alpha$-Dglucoside, methyl $\alpha$-D-mannoside, methyl $\beta$-D-xyloside, rhamnose, ribose, sorbitol, sorbose, D-tagatose, D-turanose, xylitol and D- and L-xylose are not fermented. Strains have been isolated from whisky fermentations.

The type strain is strain $\mathrm{SA}^{\mathrm{T}}\left(=\mathrm{LMG} 22464^{\mathrm{T}}=\mathrm{NCIMB}\right.$ $\left.14005^{\mathrm{T}}\right)$.

\section{Acknowledgements}

The authors thank H. Ikemoto of Suntory Ltd for the provision of strains and Suntory Ltd for funding this work. We are grateful to the owners and staff of Glenkinchie Distillery for enabling our sampling. We also thank Professor Hans G. Trüper for advice in formulation of the name.

\section{References}

Bohak, I., Back, W., Richter, L., Ehrmann, M., Ludwig, W. \& Schleifer, K. H. (1998). Lactobacillus amylolyticus sp. nov., isolated from beer malt and beer wort. Syst Appl Microbiol 21, 360-364.
Boot, H. J., Kolen, C. P., Pot, B., Kersters, K. \& Pouwels, P. H. (1996). The presence of two S-layer-protein-encoding genes is conserved among species related to Lactobacillus acidophilus. Microbiology 142, 2375-2384.

Burton, K. (1968). Determination of DNA concentration with diphenylamine. Methods Enzymol 12, 163-166.

Chavagnat, F., Haueter, M., Jimeno, J. \& Casey, M. G. (2002). Comparison of partial tuf gene sequences for the identification of lactobacilli. FEMS Microbiol Lett 217, 177-183.

Du Plessis, E. M. \& Dicks, L. M. (1995). Evaluation of random amplified polymorphic DNA (RAPD)-PCR as a method to differentiate Lactobacillus acidophilus, Lactobacillus crispatus, Lactobacillus amylovorus, Lactobacillus gallinarum, Lactobacillus gasseri and Lactobacillus johnsonii. Curr Microbiol 31, 114-118.

Falsen, E., Pascual, C., Sjödén, B., Ohlén, M. \& Collins, M. D. (1999). Phenotypic and phylogenetic characterization of a novel Lactobacillus species from human sources: description of Lactobacillus iners sp. nov. Int J Syst Bacteriol 49, 217-221.

Fujisawa, T., Benno, Y., Yaeshima, T. \& Mitsuoka, T. (1992). Taxonomic study of the Lactobacillus acidophilus group, with recognition of Lactobacillus gallinarum sp. nov. and Lactobacillus johnsonii sp. nov. and synonymy of Lactobacillus acidophilus group A3 (Johnson et al. 1980) with the type strain of Lactobacillus amylovorus (Nakamura 1981). Int J Syst Bacteriol 42, 487-491.

Gancheva, A., Pot, B., Vanhonacker, K., Hoste, B. \& Kersters, K. (1999). A polyphasic approach towards the identification of strains belonging to Lactobacillus acidophilus and related species. Syst Appl Microbiol 22, 573-585.

Horie, M., Kajikawa, H. S. \& Toba, T. (2002). Identification of Lactobacillus crispatus by polymerase chain reaction targeting S-layer protein gene. Lett Appl Microbiol 35, 57-61.

Johnson, J. L., Phelps, C. F., Cummins, C. S., London, J. \& Gasser, F. (1980). Taxonomy of the Lactobacillus acidophilus group. Int J Syst Bacteriol 30, 53-68.

Makanjuola, D. B. \& Springham, D. G. (1984). Identification of lactic acid bacteria isolated from different stages of the Scotch whisky fermentation. J Inst Brew 90, 13-19.

Mukai, T., Arihara, K., Ikeda, A., Nomura, K., Suzuki, F. \& Ohori, H. (2003). Lactobacillus kitasatonis sp. nov., from chicken intestine. Int J Syst Evol Microbiol 53, 2055-2059.

Simpson, K. L., Pettersson, B. \& Priest, F. G. (2001). Characterization of lactobacilli from Scotch malt whisky distilleries and description of Lactobacillus ferintoshensis sp. nov., a new species isolated from malt whisky fermentations. Microbiology 147, 1007-1016.

Takatani, T. \& Ikemoto, H. (2004). Contribution of bacterial microflora in malt whisky quality. In Distilled Spirits: Tradition and Innovation, pp. 197-207. Edited by J. H. Bryce \& G. G. Stewart. Nottingham: Nottingham University Press.

van Beek, S. \& Priest, F. G. (2002). Evolution of the lactic acid bacterial community during malt whisky fermentation: a polyphasic study. Appl Environ Microbiol 68, 297-305.

van Beek, S. \& Priest, F. G. (2003). Bacterial diversity in Scotch whisky fermentations as revealed by denaturing gradient gel electrophoresis. J Am Soc Brew Chem 61, 10-14.

van Loo, I. H. M., Heuvelman, K. J., King, A. J. \& Mooi, F. R. (2002). Multilocus sequence typing of Bordetella pertussis based on surface protein genes. J Clin Microbiol 40, 1994-2001.

Ventura, M. \& Zink, R. (2002). Specific identification and molecular typing analysis of Lactobacillus johnsonii by using PCR-based methods and pulsed-field gel electrophoresis. FEMS Microbiol Lett 217, 141-154. 